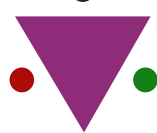

IJCRR

Section: Healthcare

Sci. Journal Impact

Factor: 6.1 (2018)

ICV: 90.90 (2018)

\title{
Significance of Tumour Markers (CEA and CA15-3) in Carcinoma Breast
}

\author{
Sujata R. Kanetkar, Ramesh M. Oswal, Mahendra A. Patil, S. J. Pawar, A. V. Mane
}

Department of Pathology, Krishna Institute of Medical Sciences Deemed To Be University, Karad, India

\section{ABSTRACT}

Introduction: Breast malignancy is a significant general medical issue for women all through the world. In the United States, breast malignant growth remains the most incessant disease in ladies and the second most frequent cause of cancer death.

Methods: Fifty cases of carcinoma of the breast in which tumour markers were studied All the cases were admitted in this institution, investigated and treated accordingly but tumour marker was sent to the outside standard laboratory, Mumbai. The cases were followed up, for a minimum period of 24 months.

Results: In 13/24 cases with abnormal CA15-3 value in postoperative follow up period, there are $54 \%$ of patients with metastatic disease. In 4/24 cases with preoperative abnormal CA15-3, metastasis occurred in 75\% and locoregional recurrence occurred in $50 \%$. In $8 / 50$ cases with preoperative abnormal CA15-3, $75 \%$ of patients are presented with locally advanced disease. In $9 / 24$ cases with abnormal CEA value in the postoperative follow-up period, there are $67 \%$ of patients with metastatic disease. In $15 / 24$ cases with preoperative abnormal CEA, metastasis occurred in 40\% and In 16/24 cases with preoperative abnormal CEA, locoregional recurrence occurred in $25 \%$. In 32/50 cases with preoperative abnormal CEA, $63 \%$ of patients are presented with locally advanced disease.

Conclusions: There is the significance of Tumour markers in carcinoma of the breast. The use of CA15-3 for early detection of metastasis seems to be promising. It appears that CA15-3 is a valuable prognostic indicator in following up of breast cancer patients as it had a significant association with both metastases and loco-regional disease.

Key Words: Tumour Markers, (CEA and CA15-3) Carcinoma, Breast

\section{INTRODUCTION}

Breast malignancy is a significant general medical issue for women all through the world. In the United States, breast malignant growth remains the most incessant disease in ladies and the second most frequent cause of cancer death. In 2007 it is that breast cancer will account for $26 \%$ of cancer cases and $15 \%$ of cancer deaths, which translates to 176,296 new cases and 40,515 deaths. ${ }^{1}$ Breast cancer was also the most common form of cancer seen in Europe in 2006, 429,900 new cases, representing $13.5 \%$ of all new cancers. ${ }^{2}$ Since 1990 , the death rate from breast cancer has decreased in the United States by $24 \%$ and similar reductions have been observed in other countries. ${ }^{3,4}$ Mathematical models suggest that both the adoption of screening mammography and the availability of adjuvant chemotherapy and tamoxifen have contributed approximately equally to this improvement. ${ }^{5}$
Although breast cancer has traditionally been less common in non-industrialized nations, its incidence in these areas is increasing. location of breast malignant growth repeat. CA15-3 levels are likewise expanded in colon, lung and hepatic tumours Roughly $50 \%$ of these recently analyzed patients are hub negative, anyway $30 \%$ of these cases progress to metastatic illness. Several tumor markers can assist clinicians with distinguishing and analyze which breast malignant growth patients will have forceful malady and which will have a lethargic course. These markers incorporate estrogen and progesterone receptors, DNA ploidy and percent-S stage profile, epidermal development factor receptor, HER-2/neu oncogene, p53 tumour silencer quality, cathepsin D, expansion markers and CA15-3. CA15-3 is generally valuable for checking patients post-operatively for the repeat, especially metastatic maladies. $96 \%$ of patients with the neighborhood

\section{Corresponding Author:}

Dr. Ramesh M. Oswal, Department of Pathology, Krishna Institute of Medical Sciences Deemed To Be University, Karad India. Email: hodpathology@kimsuniversity.in

ISSN: 2231-2196 (Print)

Received: 20.07 .2020
ISSN: $0975-5241$ (Online)

Revised: 22.08 .2020
Accepted: 4.09 .2020
Published: 22.09 .2020 
and fundamental repeat have raised CA15-3, which can be utilized to foresee repeat sooner than radiological and clinical rules. A 25\% expansion in the serum CA15-3 is related to the movement of carcinoma. A half diminishing in serum CA15-3 is related to the reaction to treatment. CA15-3 is more delicate than CEA in right on time.

Carcinoembryonic Antigen and Cancer Antigen 15-3are the most thoroughly investigated tumour markers in breast cancer. Circulating levels of CEA and CA15-3 have become established diagnostic tools as fast, noninvasive, reproducible, quantitative parameters in follow up care and monitoring therapy of breast cancer patients. CEA is a member of immunoglobulin superfamily. The human CEA quality family is grouped on chromosome $19 \mathrm{q}$ and includes 29 qualities. Of these, 18 are communicated, with 7 having a place with the CEA subgroup and 11 to the pregnancy-specific glycoprotein subgroup ${ }^{6}$. When isolated from liver metastasis, CEA is a glycoprotein consisting of $\sim 60 \%$ carbohydrate and a molecular mass of $\sim 180-200 \mathrm{kDa}$. Most of the carbohydrate is composed of mannose, galactose, $\mathrm{N}$-acetylglucosamine, fucose, and sialicacid ${ }^{7}$. CA 15-3 assay measures the protein product of the MUC-1gene located on chromosome 1q. MUC1 protein is a large transmembrane glycoprotein containing a large extracellular domain, a membrane-spanning sequence and a cytoplasmic domain. ${ }^{8,9}$

The CA15-3 is a glycoprotein, helps in cell adhesion, immunity and metastasis. ${ }^{6}$ The antigen is defined by reacting with two monoclonal antibodies DF3 and 115D8. The DF3 antibody was raised against a membrane-enriched fraction of human breast carcinoma. The 115D8 antibody was prepared against human milk fat globulin membrane and may be directed to a carbohydrate epitope. ${ }^{10}$ Serum CEA and CA15-3 are established prognostic markers in breast cancer patients. This study is aimed to correlate the serum marker levels with the clinical stage of the disease, size of the tumour, nodal status and for detecting metastasis, loco-regional recurrence in female breast cancer patients. If a correlation is found, it could provide clinicians with an indication of prognosis, thus enabling appropriate adjuvant therapy.

\section{MATERIALS AND METHODS}

This study was conducted in KRISHNA HOSPITAL and MEDICAL RESEARCH CENTRE, KARAD during the period from May 2006 to May 2008. The study comprises of a total of 50 cases that were admitted in this hospital. On admission case, history was noted and the patients were examined clinically. In this study, the TNM staging system was followed and blood samples were collected in plain bulbs. The study was approved by the Institutional Ethical Committee. Informed consent was obtained from each patient before sample collection.
Tumour markers (CEA and CA15-3) were analysed by the sandwich ELISA method using C.L.I. Technology. (Fully automated Bidirectionally interfaced Chemiluminescent Immunoassay)

CEA: 50 microlitres of the patient's samples and $100 \mathrm{mi}-$ crolitre anti-HRP (Horseradish Peroxidase) conjugate were added to the microwells coated with a monoclonal antibody (Mab). The antibody-enzyme conjugate solution contained goat anti CEA antibody conjugated to HRP. CEA is the patient's serum bound to anti-CEA MAb on the well and the anti-CEA-HRP second antibody then bound to CEA. Unbound protein and HRP conjugate were washed off by wash buffer (phosphate buffer saline). Upon the addition of the TMB (3 3' 5 5' tetramethylbenzidine) substrate, the intensity of the colour is proportional to the concentration of CEA in the samples. The colour development was stopped with the addition of stop solution $(1 \mathrm{~N} \mathrm{HCl})$.

\section{OBSERVATIONS AND RESULTS}

In 13/24 cases with abnormal CA15-3 value in the postoperative follow-up period, there are $54 \%$ of patients with metastatic disease. In 4/24 cases with preoperative abnormal CA153 , metastasis occurred in $75 \%$ and locoregional recurrence occurred in $50 \%$.In $8 / 50$ cases with preoperative abnormal CA15-3, 75\% of patients are presented with locally advanced disease. In 9/24 cases with abnormal CEA value in the postoperative follow-up period, there are $67 \%$ of patients with metastatic disease. In 15/24 cases with preoperative abnormal CEA, metastasis occurred in $40 \%$ and In 16/24 cases with preoperative abnormal CEA, locoregional recurrence occurred in $25 \%$.In 32/50 cases with preoperative abnormal CEA, $63 \%$ of patients are presented with locally advanced disease.

\section{Distribution of study subjects according to age}

In the present study, 84\%patients were in the age group 3665 years

The youngest patient in this study aged 29 years. Eldest patient aged 80 years(Table 1).

\section{Clinical stage of the disease}

In the present study, $4 \%$ of patients had stage I, $40 \%$ had stage II, $52 \%$ had stage III and $4 \%$ of patients had stage IV(Table 2 ).

\section{Relation of preoperative abnormal CEA with clinical stage}

In the present study correlation of clinical-stage in patients with preoperative abnormal CEA value. $2 \%$ patients had stage I disease.

$22 \%$ of patients had stage II disease, $36 \%$ of patients had stage III disease

$4 \%$ of patients had stage IV disease (Table 3). 
Relation of preoperative abnormal CEA with tumour size in $\mathbf{5 0}$ patients

If $\chi^{2}<3.84$ then $p>0.05$ i.e. CEA is not significantly associated with tumour size (Table 4).

\section{Relation of preoperative abnormal CEA with} axillary lymph node in $\mathbf{5 0}$ patients

If $\chi^{2}<3.84$ then $p>0.05$ i.e. CEA is not significantly associated with axillary lymph node (Table 5).

\section{Relation of preoperative abnormal CA15-3 with clinical stage}

In the present study correlation of clinical-stage in patients with preoperative abnormal CA15-3 value. $2 \%$ patients had stage I disease. $2 \%$ of patients had stage II disease. $8 \%$ of patients had stage III disease. $4 \%$ patients had stage IV disease (Table 6).

Relation of preoperative abnormal CA15-3 with tumour size in $\mathbf{5 0}$ patients

If $\chi^{2}>3.84$ then $p<0.05$ i.e. CA15-3 is significantly associated with tumour size (Table 7).

Relation of preoperative abnormal CA 15-3 with axillary lymph node in $\mathbf{5 0}$ patients.

If $\chi^{2}<3.84$ then $p>0.05$ i.e. CA15-3 is not significantly associated with axillary lymph node (Table 8).

Relation of preoperative abnormal CEA with locally advanced disease in $\mathbf{5 0}$ patients.

If $\chi^{2}<3.84$ then $p>0.05$ i.e. CEA is not significantly associated with locally advanced disease (Table 9).

Relation of preoperative abnormal CA15-3 with locally advanced disease in $\mathbf{5 0}$ patients.

If $\chi^{2}<3.84$ then $p>0.05$ i.e. CA15-3 is not significantly associated with locally advanced disease (Table 10).

\section{Relation of preoperative abnormal CEA with} locoregional recurrence in postoperative follow up 24 patients.

If $\chi^{2}<3.84$ then $p>0.05$ i.e. CEA is not significantly associated with locoregional recurrence in postoperative follow-up breast cancer patients (Table 11).

Relation of preoperative abnormal CA15-3 with locoregional recurrence in postoperative follow up 24 patients.

If $\chi^{2}>3.84$ then $p<0.05$ i.e. CA15-3 is significantly associated with locoregional recurrence in postoperative follow-up breast cancer patients (Table 12).
Relation of preoperative abnormal CEA with Metastatic disease in follow up to 24 patients. If $\chi^{2}<3.84$ then $p>0.05$ i.e. CEA is not significantly associated with metastatic disease in postoperative follow-up breast cancer patients (Table 13).

Relation of preoperative abnormal CA15-3 with Metastatic disease in follow up to 24 patients. If $\chi^{2}>3.84$ then $p<0.05$ i.e. CA15-3 is significantly associated with metastatic disease in postoperative follow-up breast cancer patients (Table 14).

\section{Relation of Postoperative abnormal CEA with} Metastatic disease in follow up to 24 patients. If $\chi^{2}>3.84$ then $p<0.05$ i.e. CEA is significantly associated with metastatic disease in postoperative follow-up breast cancer patients (Table 15).

\section{Relation of Postoperative abnormal CA15-3} with Metastatic disease in follow up to 24 patients.

If $\chi^{2}>3.84$ then $p<0.05$ i.e. CA15-3 is significantly associated with metastatic disease in postoperative follow-up breast cancer patients (Table 16).

\section{DISCUSSION}

This study was conducted in KRISHNA HOSPITAL AND MEDICAL RESEARCH CENTRE, KARAD, during the period from May 2006 to May 2008. Fifty cases of carcinoma breast in which tumour markers were studied during this period.

\section{1) Age incidence}

Breast cancer has a major impact on the health of women ${ }^{11}$. Breast cancer is the most common female-related cancer that leads to death in mostly $40-45$ years old women ${ }^{12}$

In our present study, there is a correlation between tumour size and CA15-3, not with the age of the patient.

\section{2) Tumour size and advanced clinical stage}

K. Thriveni Girija Ramaswamy showed that Measurement of serum CA15-3 showed significant correlation with tumour size and advanced clinical stage whereas measurement of serum CEA did not show any significant correlation in breast cancer patients before treatment. ${ }^{13}$

In our present study measurement of serum, CA15-3 showed significant correlation with tumour size $(25 \%)$, not with clinical stage, whereas measurement of serum CEA did not show any significant correlation with tumour size and advanced clinical stage in breast cancer patients before treatment. 
3) Tumour marker with loco-regional recurrence Bottini concluded pretreatment elevated CA15-3 levels correlated with a higher recurrence rate, further supporting the prognostic significance of this tumour marker.

Busetto M concluded the main clinical application of CA153 is for monitoring patients with diagnosed breast carcinoma and preclinically detecting recurrence. ${ }^{14}$

In the present study, pretreatment elevated serum CA15-3 is significantly associated with loco-regional recurrence. In $8 / 48$ cases with elevated pretreatment value, locoregional recurrence occurred in $50 \%$ cases.

\section{4) Tumour maker with distant metastasis}

Coveney $\mathrm{EC}^{15}$ showed elevated serum levels of CA15-3 are found more in breast carcinoma patient with distant metastasis, although the marker is rarely elevated in patients with local or primary breast carcinoma.

James TWU ${ }^{16}$ showed that CA15-3 has been elevated in $95 \%$ of cases where metastasis existed.

Hou MF and Arsalan $\mathrm{N}^{17,18}$ concluded that serum levels of CEA and CA15-3 compared and found that CA15-3 was more sensitive and specific in metastatic breast cancer than CEA.

Safi et al. ${ }^{19}$ showed that CA15-3 was significantly better than CEA in the detection of breast cancer metastasis.

In the present study, $63 \%$ patients showed an elevation in CA15-3 value. These support the fact that CA15-3 is more valuable than CEA and is gradually replacing CEA in follow up of patients with metastatic breast cancer.

CA15-3 is one of the first circulating marker shown to provide independent prognostic information in patients with breast carcinoma. CA15-3 should be a relatively noninvasive and inexpensive approach to obtain prognostic information in newly diagnosed breast cancer patient. ${ }^{20}$

It is generally agreed that tumour marker in breast cancer patients is not a tool for primary diagnosis because of their low sensitivity and specificity. ${ }^{21}$

\section{CONCLUSIONS}

There is the significance of Tumour markers in carcinoma of the breast. The use of CA15-3 for early detection of metastasis seems to be promising. It appears that CA15-3 is a valuable prognostic indicator in following up of breast cancer patients as it had a significant association with both metastases and loco-regional disease.

Acknowledgement: Authors acknowledge the immense help received from the scholars whose articles are cited and included in references to this manuscript. The authors are also grateful to authors/editors/publishers of all those articles, journals and books from where the literature for this article has been reviewed and discussed.

Conflict of interest: Nothing to report.

Source of funding: Kimsdu Karad

\section{REFERENCES}

1. American Cancer Society. Breast cancer facts and figures 20052006.

2. Ferlay J, Autier P, Boniol M, Heanue M, Colombet M, Boyle P. Estimates of the cancer incidence and mortality in Europe in 2006. Annals of oncology. 2007 Mar 1;18(3):581-92.

3. Parkin DM, Bray FI, Devesa SS. Cancer burden in the year 2000. The global picture. European journal of cancer. 2001 Sep 1;37:4-66.

4. Ries LA, Eisner MP, Kosary CL, Hankey BF, Miller BA, Clegg L, Mariotto A, Feuer EJ, Edwards BK. SEER Cancer Statistics Review, 1975-2001. Bethesda, MD: National Cancer Institute; 2004. Available on http://seer. cancer. gov/csr. 2005.

5. Berry DA, Cronin KA, Plevritis SK, Fryback DG, Clarke L, Zelen M, Mandelblatt JS, Yakovlev AY, Habbema JD, Feuer EJ. Effect of screening and adjuvant therapy on mortality from breast cancer. New England Journal of Medicine. 2005 Oct 27;353(17):1784-92.

6. Thompson JA, Grunert F, Zimmermann W. Carcinoembryonic antigen gene family: molecular biology and clinical perspectives. Journal of clinical laboratory analysis. 1991;5(5):344-66.

7. Thomas P, Toth CA, Saini KS, Jessup JM, Steele Jr G. The structure, metabolism and function of the carcinoembryonic antigen gene family. Biochimica et Biophysica Acta (BBA)-Reviews on Cancer. 1990 Dec 11;1032(2-3):177-89.

8. Duffy MJ. CA 15-3 and related mucins as circulating markers in breast cancer. Annals of clinical biochemistry. 1999 Sep;36(5):579-86.

9. Keyomarsi K, O’Leary N, Molnar G, Lees E, Fingert HJ, Pardee AB. Cyclin E, a potential prognostic marker for breast cancer. Cancer research. 1994 Jan 15;54(2):380-5.

10. Price MR, Rye PD, Petrakou E, Murray A, Brady K, Imai S, Haga S, Kiyozuka Y, Schol D, Meulenbroek MF, Snijdewint FG. Summary report on the ISOBM TD-4 Workshop: analysis of 56 monoclonal antibodies against the MUC1 mucin. Tumour Biology. 1998;19(Suppl. 1):1-20.

11. Kleer CG, Giordano TJ, Braun T, Oberman HA. Pathologic, immunohistochemical, and molecular features of benign and malignant phyllodes tumours of the breast. Modern Pathology. 2001 Mar;14(3):185-90.

12. Shooshtary MH, Talaizadeh AH, Assar S, Arnineh BK, Nateghi J, Rahdar M. Evaluation of carcinoembryonic antigen CEA and CA15. 3 tumour markers in patients operated for breast cancer. Pak J Med Sci January-March. 2007 Jan 1;23(1):115-8.

13. K. Thriven!, Lakshmi Krishnamoorthy and Girija Ramaswamy Correlation Study Of Carcino Embryonic Antigen \& Cancer Antigen 15.3 In Pretreated Female Breast Cancer Patients Indian Journal of Clinical Biochemistry, 2007:2 (1) 57-60.

14. Busetto M, Vianello L, Franceschi R, Bolzan M. CA 15-3 value and neoplastic disease predictivity in the follow-up for breast cancer. Tumour biology. 1995;16(4):243-53.

15. Coveney EC, Geraghty JG, Sherry F, McDermott EW, Fennelly JJ, O'Higgins NJ. The clinical value of CEA and CA 15-3 in breast cancer management. Int J Biol Markers 1995; 10: 35-41. 
16. James TWU. Diagnosis and management of cancer using serologic tumour markers. In: Henry JB, ed. Clinical Diagnosis and Management by Laboratory Methods.20th ed. New York: WB Saunders; 2001; 1028. 1042.

17. Hou MF, Huang TI, Hsieh JS, Huang YS, Huang CJ, Chan HM, et al. Comparison of serum CA15-3 and CEA in breast cancer. 1995;11(4): 231-234.

18. Arsalan N, Serdar M, Deveci S, Ozturk B, Narin Y, ligan S. Use of CAI5-3, CEA and prolactin for the primary diagnosis of breast cancer and correlation with the prognostic factors at the time of initial diagnosis. Ann Nucl Med 2000;14(5):395-9.

Table 1: Distribution of study subjects according to age

\begin{tabular}{lcc} 
Age in years & Number of patients & Percentage(\%) \\
$26-35$ & 4 & $8 \%$ \\
$36-45$ & 10 & $20 \%$ \\
$46-55$ & 15 & $30 \%$ \\
$56-65$ & 17 & $34 \%$ \\
Above 65 & 4 & $8 \%$ \\
\hline
\end{tabular}

Table 2: Clinical stage of the disease of study subjects

\begin{tabular}{lcc} 
Clinical stage & Number of patients & Percentage (\%) \\
I & 2 & $4 \%$ \\
II & 20 & $40 \%$ \\
III & 26 & $52 \%$ \\
IV & 2 & $4 \%$ \\
\hline
\end{tabular}

Table 3: Relation of preoperative abnormal CEA with clinical stage of study subjects

\begin{tabular}{lcc} 
Clinical stage & $\begin{array}{c}\text { Number of patients } \\
\text { with increased value }\end{array}$ & Percentage(\%) \\
I & 1 & $2 \%$ \\
II & 11 & $22 \%$ \\
III & 18 & $36 \%$ \\
IV & 2 & $4 \%$ \\
\hline
\end{tabular}

Table 4: Relation of preoperative abnormal CEA with tumour size in 50 patients of study subjects

\begin{tabular}{lccc}
$\begin{array}{l}\text { Tumour } \\
\text { size }\end{array}$ & $\begin{array}{c}\text { Patients with } \\
\text { increased } \\
\text { value }\end{array}$ & $\begin{array}{c}\text { Patients with } \\
\text { normal value }\end{array}$ & $\begin{array}{c}\text { Total number } \\
\text { of patients }\end{array}$ \\
${ }_{5} \mathrm{CM}$ & $14(54 \%)$ & $12(46 \%)$ & 26 \\
$>_{5} \mathrm{CM}$ & $18(75 \%)$ & $6(25 \%)$ & 24 \\
Total & 32 & 18 & 50 \\
\hline
\end{tabular}

19. Safi F, Kohler I, Rottinger E, Beger HE. The value of the tumour marker CA15.3 in diagnosing and monitoring breast cancer. Cancer1991; 68: 574-82.

20. Tondini C, Hayes DF, Kufe DW. Circulating tumour markers in breast cancer. Hematol/Oncol Clin North Am1989; 3; 653-74.

21. Duffy MJ, Duggan C, Keane R, Arnold DK, Hill, McDermott E. et al. High preoperative CA15-3 concentrations predict adverse outcome in node-negative and node-positive breast cancer: Study of 600 patients with histologically confirmed breast cancer. Clinical Chemistry 2004; 50:559-63.

Table 5: Relation of preoperative abnormal CEA with axillary lymph node in $\mathbf{5 0}$ patients of study subjects

\begin{tabular}{lccc}
$\begin{array}{l}\text { Axillary } \\
\text { lymph node }\end{array}$ & $\begin{array}{c}\text { Patients with } \\
\text { increased } \\
\text { value }\end{array}$ & $\begin{array}{c}\text { Patients } \\
\text { with normal } \\
\text { value }\end{array}$ & $\begin{array}{c}\text { Total } \\
\text { number of } \\
\text { patients }\end{array}$ \\
PRESENT & $15(68 \%)$ & $7(32 \%)$ & 22 \\
ABSENT & $17(60 \%)$ & $11(40 \%)$ & 28 \\
Total & 32 & 18 & 50 \\
\hline
\end{tabular}

Table 6: Relation of preoperative abnormal CA15-3 with clinical stage of study subjects

\begin{tabular}{lcc} 
Clinical stage & $\begin{array}{c}\text { Number of patients } \\
\text { with increased value }\end{array}$ & Percentage(\%) \\
I & 1 & $2 \%$ \\
II & 1 & $2 \%$ \\
III & 4 & $8 \%$ \\
IV & 2 & $4 \%$ \\
\hline
\end{tabular}

Table 7: Relation of preoperative abnormal CA15-3 with tumour size in 50 patients of study subjects

\begin{tabular}{lccc} 
Tumour size & $\begin{array}{c}\text { Patients } \\
\text { with } \\
\text { increased } \\
\text { value }\end{array}$ & $\begin{array}{c}\text { Patients } \\
\text { with normal } \\
\text { value }\end{array}$ & $\begin{array}{c}\text { Total number } \\
\text { of patients }\end{array}$ \\
$\leq 5 \mathrm{CM}$ & $2(8 \%)$ & $24(92 \%)$ & 26 \\
$>5 \mathrm{CM}$ & $6(25 \%)$ & $18(75 \%)$ & 24 \\
Total & 8 & 32 & 50 \\
\hline
\end{tabular}

Table 8: Relation of preoperative abnormal CA 15-3 with axillary lymph node in 50 patients. of study subjects

\begin{tabular}{lccc}
$\begin{array}{l}\text { Axillary } \\
\text { lymph node }\end{array}$ & $\begin{array}{c}\text { Patients with } \\
\text { increased } \\
\text { value }\end{array}$ & $\begin{array}{c}\text { Patients with } \\
\text { normal value }\end{array}$ & $\begin{array}{c}\text { Total } \\
\text { number of } \\
\text { patients }\end{array}$ \\
PRESENT & $4(18 \%)$ & $18(82 \%)$ & 22 \\
ABSENT & $4(15 \%)$ & $24(85 \%)$ & 28 \\
Total & 8 & 42 & 50 \\
\hline
\end{tabular}


Table 9: Relation of preoperative abnormal CEA with locally advanced disease in 50 patients of study subjects.

\begin{tabular}{lccc} 
CEA & Developed & Not developed & $\begin{array}{c}\text { Total } \\
\text { number of } \\
\text { patients }\end{array}$ \\
$\begin{array}{l}\text { Patients with } \\
\text { normal value }\end{array}$ & $8(44 \%)$ & $10(55 \%)$ & 18 \\
$\begin{array}{l}\text { Patients with } \\
\text { increased value }\end{array}$ & $20(62 \%)$ & $12(38 \%)$ & 32 \\
Total & 28 & 22 & 50 \\
\hline
\end{tabular}

Table 10: Relation of preoperative abnormal CA15-3 with locally advanced disease in 50 patients of study subjects.

\begin{tabular}{lccc} 
CA15-3 & Developed & Not developed & $\begin{array}{c}\text { Total } \\
\text { number of } \\
\text { patients }\end{array}$ \\
$\begin{array}{l}\text { Patients with } \\
\text { normal value }\end{array}$ & $22(52 \%)$ & $20(48 \%)$ & 42 \\
$\begin{array}{l}\text { Patients with } \\
\text { increased value }\end{array}$ & $6(75 \%)$ & $2(25 \%)$ & 8 \\
Total & 28 & 22 & 50 \\
\hline
\end{tabular}

Table 11: Relation of preoperative abnormal CEA with loco-regional recurrence in postoperative follow up 24 patients of study subjects

\begin{tabular}{lccc} 
CEA & Developed & Not developed & $\begin{array}{c}\text { Total number } \\
\text { of patients }\end{array}$ \\
$\begin{array}{l}\text { Patients with } \\
\text { normal value }\end{array}$ & $\mathrm{o}(0 \%)$ & $8(100 \%)$ & 8 \\
$\begin{array}{l}\text { Patients with } \\
\text { increased } \\
\text { value }\end{array}$ & $4(25 \%)$ & $12(75 \%)$ & 16 \\
Total & 4 & 20 & \\
\hline
\end{tabular}

Table 12: Relation of preoperative abnormal CA15-3 with loco-regional recurrence in postoperative follow up 24 patients of study subjects

\begin{tabular}{lccc} 
CA15-3 & Developed & $\begin{array}{c}\text { Not } \\
\text { developed }\end{array}$ & $\begin{array}{c}\text { Total number } \\
\text { of patients }\end{array}$ \\
$\begin{array}{l}\text { Patients with } \\
\text { normal value }\end{array}$ & $2(10 \%)$ & $18(90 \%)$ & 20 \\
$\begin{array}{l}\text { Patients with } \\
\text { increased value }\end{array}$ & $2(50 \%)$ & $2(50 \%)$ & 4 \\
Total & 4 & 20 & 24 \\
\hline
\end{tabular}

Table 13: Relation of preoperative abnormal CEA with Metastatic disease in follow up 24 patients.

\begin{tabular}{lccc} 
CEA & Developed & $\begin{array}{c}\text { Not } \\
\text { developed }\end{array}$ & $\begin{array}{c}\text { Total number } \\
\text { of patients }\end{array}$ \\
$\begin{array}{lccc}\text { Patients with } \\
\text { normal value }\end{array}$ & $\mathbf{2 ( 2 2 \% )}$ & $7(78 \%)$ & 9 \\
$\begin{array}{l}\text { Patients with } \\
\text { increased value }\end{array}$ & $6(40 \%)$ & $9(60 \%)$ & 15 \\
Total & 8 & 16 & 24 \\
\hline
\end{tabular}

Table 14: Relation of preoperative abnormal CA15-3 with Metastatic disease in follow up 24 patients.

\begin{tabular}{lccc} 
CA15-3 & Developed & $\begin{array}{c}\text { Not } \\
\text { developed }\end{array}$ & $\begin{array}{c}\text { Total number } \\
\text { of patients }\end{array}$ \\
\hline $\begin{array}{l}\text { Patients with } \\
\text { normal value }\end{array}$ & $5(25 \%)$ & $15(75 \%)$ & 20 \\
$\begin{array}{l}\text { Patients with } \\
\text { increased value }\end{array}$ & $3(75 \%)$ & $1(25 \%)$ & 4 \\
Total & 8 & 16 & 24 \\
\hline
\end{tabular}

Table 15: Relation of Postoperative abnormal CEA with Metastatic disease in follow up 24 patients.

\begin{tabular}{lccc} 
CEA & Developed & Not developed & $\begin{array}{c}\text { Total number } \\
\text { of patients }\end{array}$ \\
$\begin{array}{lccc}\text { Patients with } \\
\text { normal value }\end{array}$ & $2(13 \%)$ & $13(87 \%)$ & 15 \\
$\begin{array}{l}\text { Patients with } \\
\text { increased } \\
\text { value }\end{array}$ & $6(67 \%)$ & $3(33 \%)$ & 9 \\
Total & 8 & 16 & 24 \\
\hline
\end{tabular}

Table 16: Relation of Postoperative abnormal CA15-3 with Metastatic disease in follow up 24 patients.

\begin{tabular}{lccc} 
CA15-3 & Developed & Not developed & $\begin{array}{c}\text { Total number } \\
\text { of patients }\end{array}$ \\
$\begin{array}{l}\text { Patients with } \\
\text { normal value }\end{array}$ & $1(9 \%)$ & $10(91 \%)$ & 11 \\
$\begin{array}{l}\text { Patients with } \\
\text { increased } \\
\text { value }\end{array}$ & $14(54 \%)$ & $6(46 \%)$ & 13 \\
Total & 8 & 16 & 24 \\
\hline
\end{tabular}

